\title{
Ondersteuning van het besliskundig denken van de huisarts
}

Citation for published version (APA):

Buntinx, F. (2000). Ondersteuning van het besliskundig denken van de huisarts. Maastricht University. https://doi.org/10.26481/spe.20001110fb

Document status and date:

Published: 10/11/2000

DOI:

$10.26481 /$ spe.20001110fb

Document Version:

Publisher's PDF, also known as Version of record

\section{Please check the document version of this publication:}

- A submitted manuscript is the version of the article upon submission and before peer-review. There can be important differences between the submitted version and the official published version of record.

People interested in the research are advised to contact the author for the final version of the publication, or visit the DOI to the publisher's website.

- The final author version and the galley proof are versions of the publication after peer review.

- The final published version features the final layout of the paper including the volume, issue and page numbers.

Link to publication

\footnotetext{
General rights rights.

- You may freely distribute the URL identifying the publication in the public portal. please follow below link for the End User Agreement:

www.umlib.nl/taverne-license

Take down policy

If you believe that this document breaches copyright please contact us at:

repository@maastrichtuniversity.nl

providing details and we will investigate your claim.
}

Copyright and moral rights for the publications made accessible in the public portal are retained by the authors and/or other copyright owners and it is a condition of accessing publications that users recognise and abide by the legal requirements associated with these

- Users may download and print one copy of any publication from the public portal for the purpose of private study or research.

- You may not further distribute the material or use it for any profit-making activity or commercial gain

If the publication is distributed under the terms of Article $25 \mathrm{fa}$ of the Dutch Copyright Act, indicated by the "Taverne" license above, 


\title{
Ondersteuning van het besliskundig denken van de huisarts.
}

\author{
Prof. Dr. Frank Buntinx
}

Rede uitgesproken bij de aanvaarding van het ambt van

Bijzonder Hoogleraar in de

Klinische Epidemiologie in de Eerstelijnsgeneeskunde aan de Faculteit Geneeskunde van de Universiteit Maastricht op vrijdag 10 november 2000 
Wenn ich in deine Augen seh'

Wenn ich in deine Augen seh:

So schwindet all " mein Leid and Weh,

Doch wenn ich küsse deinen Mund,

So werd' ich ganz und gar gesund.

R.Schumamn 
Dames en heren,

Huisartsen nemen tegenwoordig geen beslissingen meer in plaats van hun patiënten. Vroeger werd algemeen aanvaard dat artsen hun patiènt vertelden wat hij of $z i j$ moest doen: "U moet geopereerd worden, $U$ nnoet dit geneesmiddel innemen of $U$ mag geen kinderen meer krijgen." Tegenwoordig proberen huisartsen hun patienten zo goed mogelik voor te lichten en te begeleiden, maar de eindbeslissingen worden door de mensen zelf genomen: "Als $U$ in uw situatie dit geneesmiddel neemt, kan $U$ daar dat effect van verwachten. Als $U$ op veertig jaar zwanger wordt, heeft $U$ een kans van éen op 100 op een mongooltje." De consequenties zijn duidelijk, maar de eindbeslissing ligt bij de patiënt en bij hem of haar alleen.

Huisartsen nemen tijdens hun klinisch werk voortdurend beslissingen, tientallen, misschien honderden per dag. En vaker dan men denkt hebben die beslissingen direct of indirect consequenties met betrekking tot het leven en de dood van hun patiënten, tot een kortere of langere tijd van ziek zijn of lijden, tot meer of minder kans op handicap of verdriet, tot meer of minder kosten, in geld, in tijd, in pijn of angst en onrust: 'Zal ik deze patiënt dit of dat geneesmiddel voorschrijven? Zal ik deze patiènt met pijn op de borst geruststellen, zal ik een ecg maken of een radiografie aanvragen, zal ik medicatie of fysiotherapie voorschrijven of zal ik een ziekenhuisopname voorstellen? In dat laatste geval, hoe dringend is dat dan en hoe sterk zal ik daar op aandringen? Soms lijkt de beslissing voor de hand te liggen, soms kan het ook erg moeilijk zijn en vrijwel zonder uitzondering is er telkens een kans op een fout, want honderd procent zekerheid is er in dit soort werk nooit.

Huisartsen nemen dit soort beslissingen niet zomaar. Zij doen dit op basis van kennis en ervaring. Velen onder $U$ zullen wertrouwd zijn met de engelse termen evidence en experience als basis voor het klinisch handelen.

De ervaring die een huisarts opbouwt, kan na verloop van tijd erg rijk zijn. Een deel van deze ervaring is ook de ervaring opgedaan met deze patiënt die nu voor mij zit. Kennis over de beste aanpak van een bepaalde situatie wordt in het dagelijks werk altijd vertaald naar de heel eigen situatie van iedere patiënt: uiteraard is de best mogelijke behandeling waardeloos als een patiënt er allergisch voor is, maar er spelen ook 
andere dingen: als een patiënt voor de dood is voor een bloedafname, zal ik binnen zekere grenzen proberen hem die te besparen. Sommige mensen zijn bereid veel geld, moeite en zorg te investeren om zekerheid te krijgen over de precieze aard van hun probleem, voor anderen geldt dat minder. Alleen al het vermelden van de mogelijkheid van aanvullend. onderzoek kan sommige mensen heel erg bang maken of hen fixeren in wat Richard Grol, Frans Huijgen en hun collega's in Nijmegen vele jaren geleden reeds somatische fixatie noemden. Het voortdurend inschakelen van de eigen ervaring door de arts is essentieel. Anderzijds is de ervaring van iedere individuele arts, hoe rijk ook, tevens erg wisselend, weinig systematisch en moeilijk overdraagbaar naar anderen, bijvoorbeeld naar mensen in opleiding.

Daarenboven is er ondertussen in de wereld zoveel kennis opgebouwd en onderbouwd dat dit in de meeste situaties een goede basis vormt voor het handelen van de arts en voor de beslissingen die moeten genomen worden. Deze kennis kornt niet uit de lucht gevallen; zij komt van gedegen research en is vaak moeizaam verworven met inzet van veel tijd, energie en middelen door velen.

Beslissingen van huisartsen worden beïnvloed door velerlei soorten onderzoek. Als in het laboratorium of op de tekentafel van de moleculaire bioloog een nieuw geneesmiddel ontdekt wordt of een nieuwe analysetechniek ontwikkeld, zal dat vroeg of laat wellicht het handelen van de huisarts beinvloeden. Dat zal echter niet meteen het geval zijn en ook niet rechtstreeks. Onderzoek dat het handelen van huisartsen het meest direct beïnvloed is onderzoek dat gebeurt bij 'echte mensen', het patiêntgebonden onderzoek. Vaak komt het erop neer dat men iets onderzoekt bij een groep mensen met een gemeenschappelijk kenmerk, bijvoorbeeld een bepaalde aandoening in een bepaald stadium. Men gaat er dan van uit dat wat goed is voor een zekere proportie van deze mensen met een gelijke kans ook goed is voor iedere individuele volgende patiënt met dezelfde aandoening in een vergelijkbaar stadium. Dergelijk patiëntgebonden onderzoek in groepen mensen, waarvan de resultaten dienen ter ondersteuning van medisch handelen bij individuen, wordt klinisch epidemiologisch onderzoek genoemd. Het is dit type onderzoek dat de belangrijkste onmiddellijke ondersteuning en onderbouwing moet bieden voor de keuzen die een huisarts moet maken en voor de beslissingen die hij moet nemen. 
Het is goed dat wij ons realiseren dat het huisartsgeneeskundig klinisch werk veel gemeen heeft met andere disciplines en takken van de geneeskunde, maar dat er ook een aantal heel eigen kenmerken zijn.

1. Een huisarts wordt geconfronteerd met een zeer brede waaier van aandoeningen en problemen, veel breder dan in eender welk ander specialisme. Mede als gevolg daarvan komt eender welke aandoening in de huisartsgeneeskundige praktijk relatief zelden voor (lage prevalentie geneeskunde).

2. Huisartsen worden vaak geconfronteerd met een klinisch beeld of met keuzen die vertroebeld worden door het tegelijkertijd aanwezig zijn van andere aandoeningen (co-morbiditeit). Dit verschijnsel neemt sterk toe met toenemende leeftijd.

3. Een huisarts verzorgt nooit een ziekte, maar een persoon waarvan hij ook veel andere aspecten kent en mee in zijn beschouwingen moet betrekken: er is een voorgeschiedenis, maar ook een meer of minder beperkte psychologische draagkracht, misschien financiële beperkingen of een gezinssituatie die erg stimu lerend, maar ook erg belastend kan zijn. 4. Een huisarts werkt vaak met niet enkel een individuele patiënt in het achterhoofd, maar ook diens gezin. Er bestaat een duidelijke wisselwerking tussen het ontstaan en de evolutie van ziekten en de interacties binnen het huishouden waarin de patiënt leeft, ook al is deze wisselwerking zeker nog onvoldoende uitgeklaard.

Veel van het patiëntgebonden onderzoek gebeurt door clinici, die voor een deel van de tijd hun petje van clinicus afzetten en het petje van de onderzoeker opzetten. Ik wil U vandaag één en ander vertellen over wat er gebeurt als zo een clinicus opeens onderzoeker wordt, hoe hij probeert het klinisch handelen te ondersteunen, maar daarbij gebruik maakt en moet maken van de concepten en vereisten uit de wereld van de research. De voorbeelden die ik daarbij gebruik, komen alle uit werk dat tijdens de laatste jaren is verricht aan de afdeling huisartsgeneeskunde, hier in Maastricht of in Leuven. Het is dan ook geen toeval dat veel van de aandacht zal gaan naar diagnose en minder naar interventies. Beide afdelingen hebben immers juist op dit terrein een belangrijk deel van hun faam verworven.

Ik heb enkele concrete vragen uitgekozen, waar ik vaindaag samen met $\mathrm{U}$ dieper op wil ingaan:

Wat gaat er allemaal om in het hoofd van een huisarts die probeert een diagnose te stellen en op basis warvan neemt hij zijn beslissingen? Hoe 
kijkt een onderzoeker naar dit proces en hoe verzamelt hij de informatie waarmee hij de clinicus kan ondersteunen? Wat is de rol van metaanalyse bij dit alles?

Hoe belangrijk is co-morbiditeit en welke gegevens zijn beschikbaar om de relaties tussen het voorkomen vari verschillende ziekten bij een zelfde persoon te bestuderen?

Waarom is het zo moeilijk om de relatie te bestuderen tussen gezinsinteracties enerzijds en ziekte en gezondheid anderzijds?

Het stellen van een diagnose.

Zonder daar verder veel bij stil te staan, zijn er een aantal technieken die een huisarts gebruikt bij het stellen van een diagnose: soms is er een beeld dat hij - al dan niet- meteen herkent: mazelen, windpokken of zona zijn dergelijke aandoeningen. Dat noemt men een spotdiagnose. Soms wordt een hele batterij van allerlei technologische testen op een patiënt losgelaten in de hoop van op deze wijze achter de diagnose te komen. Dat is een techniek die vooral in het ziekenhuis gebruikt wordt. In de huisartspraktijk is dit uitzonderlijk. Ook vooral in het ziekenhuis wordt vaak gebruik gemaakt van algoritmes. Daarbij leidt ieder testresultaat tot een volgende test volgens een op voorhand vastgelegd schema, tot de definitieve diagnose gevonden is. Vooral in de spoedgevallenzorg is een dergelijke aanpak populair. Huisartsen werken echter het vaakst volgens een model dat men met een moeilijke term het hypothetico-deductief model noemt. Binnen de eerste minuten van het contact formuleert de arts drie tot vijf mogelijke hypothesen. Via allerhande testen zal hij deze hypothesen dan gaan toetsen. Sommige hypothesen worden daarbij uitgesloten, andere winnen progressief aan waarschijnlijkheid. Testresultaten kunnen ook tot gevolg hebben dat nieuwe hypothesen opduiken en mee in de redenering betrokken worden. De Werkgroep Medische Besliskunde van de WVVH heeft dit enige jaren geleden mooi beschreven als een diagnostisch landschap waarvan het reliëf voortdurend verandert. Sommige heuvels verdwijnen geleidelijk als gevolg van de onderzoeksresultaten, terwijl andere uitgroeien tot volwassen diagnostische bergen.

Testen of onderzoeksresultaten dient men daarbij te verstaan in de meest brede zin van het woord. Het gaat daarbij om alle informatie die de arts over de patiënt verzamelt: achtergrondgegevens zoals leeftijd, geslaclat en reeds bestaande ziekten, klachten, symptomen bij het lichamelijk 
onderzoek en resultaten van aanvullend onderzoek van bloed, urine, beeldvorming en wat al meer zij.

Het lijkt er soms op dat de huisarts dit diagnostisch proces op een intuitieve manier doet, zonder dat daar veel echte formele redeneringen bij te pas komen en misschien is dat ook wel zo. Toch is diagnostiek niet zomaar een gave die men heeft of niet heeft. Zo is jaren geleden hier in Maastricht reeds vastgesteld dat ervaren huisartsen correcter diagnosen stellen dan nieuwelingen of studenten.

Wat zich in het hoofd van de huisarts afspeelt is meer dan alleen maar zijn of haar bewuste redeneringen. Het is dan ook heel moeilijk om zicht te krijgen op wat er gebeurt. Toch leeft in brede kringen de mening dat huisartsen, zij het niet volkomen bewust, werken met een systeem van kansberekening, waarbij de kans op een bepaalde diagnose onder invloed van testresultaten stijgt of daalt. Daarbij worden niet alleen de aangeboden klachten en symptomen betrokken, maar ook de context; zijnde het geheel van alle informatie waarover de huisarts beschikt met betrekking tot de leefwereld en de voorgeschiedenis van de patiënt. Op een bepaald ogenblik wordt er dan een drempel overschreden waarbij de kans op een bepaalde diagnose zo klein wordt dat dit verder voorlopig kan genegeerd worden, ofwel zo groot dat op basis daarvan verder handelen aangewezen is. Dat handelen kan dan bestaan uit het starten van een behandeling of uit het plannen van verder aanvullend onderzoek. Uiteraard worden deze kansen niet uitgedrukt in getallen of percentages, maar gaat het on grootte-orden. Het is niet helemaal bekend hoe deze kansen bepaald worden, maar wellicht gaat het ook hier om een combinatie van verworven kennis en van ervaring, weer eens: evidence en experience.

Er is dus toch wel wat te leren. En als er wat te leren valt, komt de onderzoeker terug op het toneel, want die moet zorgen voor de productie wan gesystematiseerde kennis, kennis die aan anderen overdraagbaar is. Laat ons dus nu eens kijken hoe de onderzoeker naar diagnostiek kijkt. want dat is allesbehalve intuitief.

\section{Diagnostisch wetenschappelijk onderzoek.}

De eenvoudigste situatie is die waarbij een test negatief of positief is, ja of neen (dus niet meer of minder) en waarbij beslist moet worden of éen bepaalde ziekte al dan niet aanwezig is. De onderzoeker doet de test die bestudeerd wordt bij een grote groep proefpersonen. Tegelijkertijd doet 
hij bij al die mensen een gouden standaard test, een test die soms erg moeilijk, duur of belastend is, maar die de aandoening met een zo groot mogelijke kans op zekerheid vastlegt. Bij gezwellen zou dat bijvoorbeeld een biopsie kunnen zijn of een operatie. De kans op ziekte (eigenlijk de kans op een positieve gouden standaard test) of niet-ziekte wordt in deze groep mensen dan vergeleken met de kans op een positieve of negatieve testuitslag. De getallen die daarbij horen worden bij elkaar gebracht in een twee maal twee tabel, de werktafel van de klinisch epidemioloog. Klinisch epidemiologen zijn rare mensen: zij denken en dromen in termen van twee maal twee tabellen. Er zijn allerhande maten waarin deze relatie tussen test en gouden standaard dan uitgedrukt wordt: de gevoeligheid, de specificiteit, de woorspellende waarde van een positieve of negatieve testuitslag en de likelihood ratio van een positieve of negatieve testuitslag of met de mooie nederlandstalige term die de mensen van de WVVH Werkgroep Medische Besliskunde daarvoor bedachten: de (diagnostische) kracht van het argument.

Dit is eigenlijk allemaal vrij simpel en sluit nauw aan bij het denken van de huisarts. Ik palpeer de buik van iemand met buikpijn en als ik op de maag duw, doet dat duidelijk pijn. De kans op een maagzweer wordt daardoor $\mathrm{x}$ maal groter (dat is dan een vertaling van de kracht van deze drukpijn als argument ten voordele van de diagnose maagzweer) of de kans op een maagzweer die aanvankelijk bijvoorbeeld $10 \%$ was, wordt nu 40 of $50 \%$, wat meteen betekent dat er een drempel overschreden is, die maakt dat het nu ruim verantwoord is om een vervelend onderzoek zoals een gastroscopie aan te vragen. Intuitief en zonder daar meteen getallen op te plakken hoort dit tot het dagelijks redeneren van de huisarts.

Uiteraard is het toch niet altijd even eenvoudig en komt er soms toch wel wat meer bij kijken.

1. Van veel testen kennen wij zelfs deze elementaire gegevens niet. Het diagnostisch onderzoek staat lang niet zo ver als het onderzoek waarbij het effect van allerlei behandelingen bestudeerd wordt. Daarenboven is veel van de kennis die wel beschikbaar is afkomstig van ervaringen en onderzoek uit universitaire ziekenhuizen met een heel speciale selectie van patiënten die drastisch verschilt van de selectie die men in de hu isartspraktijk aantreft. Wij hebben reeds gezien dat dergelijke kennis niet zonder meer naar de huisartsgeneeskunde overdraagbaar is. Een goede test die ons veel leert in de huisartsgeneeskunde kan waardeloos zijn in het ziekenhuis en omgekeerd. Zo is bloedverlies bij de stoelgang 
op de afdeling darmziekten van het ziekenhuis een behoorlijk goede voorspeller voor de aanwezigheid van darmkanker. In de huisartspraktijk geldt dit veel minder en eigenlijk alleen boven de zestig jaar. Op wereldschaal zijn wij daarom als vakgebied nu bezig on zo ongeveer de hele medisch-diagnostische kennis te herbekijken en ten dele te herschrijven. Dat is een ongecoördineerd gebeuren, waarbij echter honderden onderzoekers continu betrokken zijn en waarmee wij nog voor de rest van deze generatie bezig zullen zijn.

2. Het gaat niet altijd om alleen maar ja-neen resultaten: een testuitslag kan ook een uitslag op een continue schaal zijn. Zo kan de bloeddruk ons misschien iets leren over de kans op hartinfarct bij mensen met pijn op de borst, maar de bloeddruk is niet ja of neen, maar meer of minder. Een dergelijke relatie krijgt zelfs een klinisch epidemioloog niet meer in een twee maal twee tabel uitgedrukt. Eigenlijk gaat het dan om een heleboel twee maal twee tabellen, eentje voor iedere mogelijke waarde van de bloeddruk. Al deze resultaten worden dan samengevat in een ROC curve en de vorm van deze ROC curve geeft ons een idee over hoe goed deze test ons helpt bij het diagnosticeren van de ziekte. Als de curve de diagonaallijn volgt, leert de test ons niets. Wij kunnen even goed een muntstuk opgooien. Hoe meer de curve zich verplaatst naar de linker bovenhoek, hoe meer wij uit de curve leren. In getallen drukken wij dit uit als de oppervlakte onder de curve: als die 1 is (of 100\% van wat mogelijk is), dan hebben wij een perfecte test. Als de oppervlakte 0.5 is (of $50 \%$ van wat maximaal mogelijk is), dan hebben wij een perfect waardeloze test. Nog een voorbeeld van een dergelijke situatie is het gebruik van verschillende min of meer korte vragenlijsten voor de diagnose van problematisch alcoholgebruik, waarbij wij zoals Bert Aertgeerts het deed, mooi kunnen vergelijken welke vragenlijst uit een reeks van mogelijkheden de beste is.

Het kan ook zijn dat zowel de testuitslag als de waarde van de gouden standaard zich uitdrukken op een continue schaal. Als wij de nierfunctie bestuderen zullen wij bijvoorbeeld willen weten of de creatininebepaling een goede test is en of die beter of slechter overeen komt met de gouden standaard test dan de ureumbepaling. De gouden standaard test maakt dan bijvoorbeeld gebruik van ingespoten radio-actieve merkers waarvan de uitscheiding in de urine gevolgd wordt en ook die waarden drukken zich uit op een contimue schaal. Voor dergelijke relaties maken wij gebruik van correlatiefactoren en van regressievergelijkingen. Dat zijn moeilijker 
statistische hulpmiddelen waarmee clinici meestal minder vertrouwd zjjn. Conceptueel zijn het echter allemaal variaties op een zelfde thema: in welke mate voorspelt een testuitslag de aanwezigheid of de mate van ziekte (of nawkeuriger: het gouden standaard resultaat)?

3. De meeste diagnostische testen zijn asymmetrisch van natuur. Dit betekent dat een test die goed is als bevestiger van een aandoening al te vaak slecht is alls uitsluiter van diezelfde aandoening en omgekeerd. Het meest klassieke voorbeeld daarvan is het ecg bij een patiënt die misschien een hartinfarct heeft. Als het ecg in de acute fase een Pardee-curve vertoont, is het quasi zeker dat deze patiēnt een infarct aan het ontwikkelen is. Als het ecg normal is daarentegen, leert dat ons nawwelijks iets. Het is best mogelijk dat er toch een infarct is, maar dat de ecgafwijkingen slechts enige tijd later zullen optreden. Dat is de reden waarom de meeste huisartsen in een dergelijke situatie geen ecg zullen maken, ook niet in België, waar de meeste huisartsen een apparaat bezitten en er regelmatig gebruik van maken. Als het ecg afwijkend is, bevestigt het alleen wat toch reeds verondersteld was. Het heeft dan allleen tijd gekost, die beter voor andere dingen gebruikt kon worden. Is het normaal, dan kan het de huisarts alleen aan het aarzelen brengen en misschien een foute beslissing tot gevolg hebben. In het ziekenhuis daarentegen, zal bij diezelfde patiënt zeker een ecg gemaakt worden. De patiënt komt daar echter in het beste geval een kwartiertje later binnen en de kans op cen fout negatief resultaat is er nauwelijks nog aanwezig. Een dergelijke asymmetrie in de bruikbaarheid van testen is meer regel dan witzondering. Het is dan ook daarom dat wij altijd tenminste twee maten nodig hebben om de kwaliteiten van een test te beoordelen, bijvoorbeeld de voorspellende waarde of de likelihood ratio van een positieve testuitslag, samen met die van een negatieve testuitslag.

4. Wij beginnen bij het diagnosticeren nooit van nul. Als een patiënt bij mij op de raadpleging binnenkomt, zie ik meteen dat het een man of een vrouw is, dat hij of zij tot en bepaalde leeftijdsgroep behoort en meer of minder ziek lijkt. Dat zijn al drie testuitslagen die ik cadeau krijg, nog voor ik zelfs maar goedendag gezegd heb. Als ik mijn eerste vraag stel, weet ik dus al heel wat en ook dat moet de onderzoeker in mij in mijn diagnostisch redeneren betrekken.

Het probleem is dat vrijwel alle diagnostische research die op dit moment in de wereld beschikbaar is, dit volkomen negeert. Telkens wordt een test 
onderzocht alsof het de enige test is die bestaat en alsof er geen andere informatie beschikbaar is. Researchers die hier well rekening mee gehouden hebben, werken met één of andere variant van beslisbomen: als test 1 positief is, doen wij test 2 en als die dan ook positief is, trekken wij daar dat besluit uit; maar als test 1 negatief was, is dat weer anders, enzovoort. Technisch kunnen wij dergelijke beslisbomen vaak gewoon met de hand ontwerpen, zoals Bert Aertgeerts gedaan heeft voor de vroegdiagnose van problematisch alcoholgebruik, of wij kunnen werken met speciaal daarvoor ontworpen computerprogramma's zoals CART, dat wij in samenwerking met de biostatistici van Diepenbeek gebruikten voor het onderzoek bij mensen met pijn op de borst; of wij kunnen werken met multiple logistische regressie, zoals André Knottnerus hier in Maastricht misschien wel voor het eerst in de wereld deed, onder meer met de onderzoekersgroep rond perifeer vaatlijden. De laatste techniek is de meest gesofisticeerde en moeilijkste, maar hij zit wel vol mogelijkheden, die nog lang niet allemaal volledig uitgeprobeerd zijn. Eén van de mogelijkheden is dat wij het programma wat forceren, zodat wij eenvoudige testen eerst onderzoeken en daarna geleidelijk testen aanbieden die moeilijker uit te voeren zijn, of duurder, of belastender voor de patiënt. Deze laatste testen zullen in het eindbesluit dan slechts een rol spelen als zij niet alleen iets bij kunnen brengen aan het proces van de diagnose-stelling, maar als zij iets bijbrengen dat een extra aanwinst is bovenop wat wij reeds weten uit de resultaten van de eenvoudiger onderzoeken. Deze techniek werd bijvoorbeeld gebruikt door Jan De Lepeleire in zijn onderzoek over de vroegdiagnose van dementie. Het is toch wel met enige trots dat ik vaststel dat diagnostisch onderzoek waarbij resultaten van meerdere testen samen gebruikt worden uit slechts enkele plaatsen in de wereld afkomstig is en dat groepen uit Maastricht, Utrecht en Leuven daarbij telkens mee aan de frontlijn blijken te staan.

Moeilijke statistische technieken hoeven daarom niet te leiden tot moeilijke resultaten. De zonet vermelde onderzoeken resulteerden uiteindelijk in relatief eenvoudige algoritmen, die zonder grote problemen in de huisartspraktijk toepasbaar zijn. Het gaat daarbij meestal om een reeks van niet meer dan een vijftal testen. Voor het identificeren van deze reeks was echter wel een onderzoek van vele jaren nodig en de inzet van onderzoekers uit verschillende disciplines.

5. In het huisartsgeneeskundig wetenschappelijk onderzoek is een gouden standaard vaak niet zo eenvoudig te vinden. Wij kunnen nu eenmaal 
moeilijk enkele honderden mensen met bloedverlies bij de stoelgang of bij de urine systematisch allemaal laten opereren om met zekerheid te weten of zij al dan niet een kanker hebben. Wij moeten dan terugvallen op referentiematen die wat minder goud zijn. Daarbij wordt nogal eens gebruik gemaakt van de gewone routinegewijze klinische opvolging. De mensen uit de onderzoeksgroep krijgen dan geen enkel systematisch bijkomend onderzoek alleen omwille van het researchproject waarin zij een rol spelen. Zij krijgen de onderzoeken die zij ook zouden krijgen als er geen onderzoeksproject was, niet meer, niet minder. De behandelend geneesheer doet precies hetgeen hij of zij anders zou doen. Alleen wordt wel alles heel zorgvuldig geregistreerd. Wij gaan dan uit van de veronderstelling dat als liemand de onderzochte aandoening heeft, dat binnen een bepaalde periode hoe dan ook zal blijken, zelfs indien de diagnose aanwankelijk gemist zou zijn. $Z$ o is het bijvoorbeeld redelijk te veronderstellen dat als iemand vandaag darmkanker zou hebben, zulks hoe dan ook binnen één of twee jaar wel zal gebleken zijn uit de normale klinische evolutie. Het onderzoek wordt dan pas afgesloten na verloop van deze opvolgingsperiode en de einddiagnose (op basis van wat wij dan meestal de referentiestandaard noemen in plaats van de gouden standaard) is gebaseerd op alle routinematig verzamelde informatie die in de loop van de tijd verzameld is over deze patiënt. Deze methode werd ruim tien jaar geleden hier in Maastricht voor het eerst zorgvuldig beschreven door de groep met Jean Muris, Gerda Fyten, Richard Stamans en André Knottnerus tijdens hun onderzoek rond buikklachten. Deze werkwijze is ondertussen overal in de wereld overgenomen.

6. Huisartsen gebruiken bij het diagnosticeren regelmatig twee testen die andere artsen valk wat eigenaardig in de oren klinken: het pluis-niet pluis gevoel en de factor tijd. Het niet pluis gevoel is de indruk die de huisarts krijgt als hij een patiẻnt onderzoekt dat er iets niet klopt, dat er iets aan de hand is dat ernstig is, ook al weet hij of $2 \mathrm{ij}$ niet steeds wat er precies aan de hand is. Huisartsen hebben alle reden om dat gevoel heel erg au serieus te nemen. Toen wij enige jaren geleden een diagnostisch onderzoek deden bij mensen met pijn op de borst, bleek deze "test" de betrouwbaarste voorspeller te zijn voor een ernstige aandoening, veel meer dan bijvoorbeeld het hartritme of de bloeddruk. Bij een vergelijkbaar onderzoek dat enige tijd later liep op de spoedgevallendienst van het Leuvens universitair ziekenhuis was dit veel minder het geval. Betekent dit dat het pluis-niet pluis gevoel alleen 'des huisartsen' is? Of heeft dit te 
maken met het feit dat de eerste opvang en dus ook de registratie in een ziekenhuis vooral door jonge en dus gemiddeld minder ervaren assistenten gebeurt? Er is in het verleden kritiek geut op dit begrip en terecht overigens. Wellicht gaat het on een combinatie van testuitslagen die op een niet helemaal bewuste wijze op éen hoop gegooid worden. Daarenboven wordt het begrip wellicht door verschillende artsen niet helemaal gelijk geinterpreteerd. Toch leerde ons onderzoek dat het een belangrijk, als het ware ingebouwd waarschuwingshchte is, waar huisartsen best terdege rekening mee houden.

7. Huisartsen zien aandoeningen als regel in een relatief vroeg stadium. Vaak is het beeld dan ook nog niet volledig ontwikkeld en allesbehalve klassiek. Een diagnose stellen kan dan erg moeilijk zijn. Wanneer een beeld niet meteen duideligk is en wanneer het niet on ernstige, acute of erg belastende problemen gaat, is het vaak nuttig om te zien wat er gebeurt als er enkele dagen afgewacht wordt. Soms is alles opgeklaard en is iedereen gelukkig, ook al is de precieze oorzaak van de klachten niet bekend. Als dat niet het geval is, is het beeld ondertussen meestal een stuk duidelijker geworden en kan er gepast op gereageerd worden. U kan zich voorstellen dat het vertalen van dit mechanisme in onderzoeksvragen voor het opzetten van research vrijwel ondoenbaar is.

8. Tot nu toe heb ik het over diagnostisch onderzoek gehad alsof het de tak van de arts is om éen bepaalde aandoening te diagnosticeren of uit te sluiten. Ook in het wetenschappelijk onderzoek is dat tot dusver trowwens meestal het geval geweest. Bij een patiënt met pijn op de borst zocht men naar een werkwijze om zo goed mogelijk vast te stellen of die al dan niet een hartinfarct had. Ook al is het de bedoeling van acuut levensgevaarlijke aandoeningen eerst te bevestigen of uit te sluiten, daarmee stoppen is naturunk onin. Als huisarts is het mint tak om vast te stellen wat aan de hand is en als onderzoeker is het minn taak on de huisartsen daar hulpmiddelen bij te geven en dan gaat het on veel meer dan alleen een hartinfarct. Bij het onderzoek bij mensen met pijn op de borst inventariseerden wij zo 67 verschillende aan de klacht 'pijn op de borst" gerelateerde diagnosen. Er zin tot dusver weing technieken beschikbaar on de relatie tussen een reeks van testuitslagen en cen reeks van mogelike diagnosen te analyseren. CART software, het computerprogramma voor het maken en analyseren van complexe beslisbomen waarover ik het vroeger reeds had, is én van de weinge waar ervaring 
mee opgedaan is. De keuzen die gemaakt worden telkens er een nieuwe testuitslag bij ingevoerd wordt, zijn echter gebaseerd op louter statistische significanties en dat is niet wat de clinicus het belangrijkste criterium vindt. Gewone logistische regressie-analysen werken met slechts én einddiagnose. Polytome logistische regressietechnieken moeten op dit gebied mogelijkheden kumnen bieden, maar daar is nog vrijwel geen ervaring mee opgedaan. Wellicht wordt het oplossen van deze problematiek eén van de belangrijke uitdagingen voor de volgende jaren.

\section{De diagnostische meta-analyse}

Ik heb $U$ tot nu toe een idee proberen te geven van een aantal problemen die zich stellen met betrekking tot de diagnostiek in de huisartsgeneeskunde en van de manier waarop klinisch epidemiologen proberen om daar in hun wetenschappelijk onderzoek antwoorden voor te vinden. Resultaten van wetenschappelijk onderzoek bestaan maar als zij gepubliceerd worden. Wijze lessen die in de bureaulade van de onderzoeker blijven liggen zijn volstrekt zinloos en eigenlijk onbestaande, want voor niemand bruikbaar. Het medium waarlangs het resultaat van een wetenschappelijk onderzoek in de geneeskunde verspreid wordt, is het researchartikel in een wetenschappelijk tijdschrift. Rechtstreeks of onrechtstreeks is dat het kanaal dat de researcher gebruikt om zijn bevindingen mee te delen aan zijn klinisch werkende collegae. Alleen, er bestaan op dit ogenblik ongeveer 20.000 biomedische tijdschriften, waarin jaarlijks twee miljoen artikelen verschijnen en ik ken geen enkele arts die jaarlijks twee miljoen artikelen leest. Daarenboven hebben researchresultaten nogal eens de neiging elkaar tegen te spreken, soms overigens op goede gronden. Het kan voor clinici erg moeilijk zijn daar hun weg in te vinden. Systematische literatuuroverzichten moeten hen dararj op een betrouwbare en efficiènte wijze bij helpen

Vooral onder invloed van de Cochrane Collaboration is er tijdens de voorbije vijftien jaren een wereldwijde beweging op gang gekomen om het maken van dergelijke reviews niet alleen te stimuleren, maar ook aan kwaliteitscriteria te onderwerpen. In grote lijnen komt het er op neer dat alle stappen bij de productie van het overzichtsartikel zoveel mogelijk geêxpliciteerd worden. Als de resultaten van de verzamelde artikelen ook nog gebundeld (statistisch gepoold) worden tot éen samenvattend resultaat, spreekt men van een meta-analyse. Eigenlijk zou iedere arts 
tegenwoordig moeten beschikken over de CD-ROM met de Coehrane Library, die ieder trimester aangevuld wordt.

Het is een bewuste politiek van de Cochrane Collaboration dat de beschikbare energie tot nader order volledig toegespitst wordt op metaanalysen waarin het effect bestudeerd wordt van interventies, bijvoorbeeld het effect van een geneesmiddel op de genezing van een bepaalde ziekte. Diagnostisch onderzoek valt hier buiten. Toch is er de laatste jaren aan enkele centra in de wereld hard gewerkt aan het maken van diagnostische meta-analysen en aan de ontwikkeling van de daarvoor noodzakelijke methodologie en statistische software. De MEDION groep, waarin verschillende afdelingen van de Maastrichtse Universiteit samenwerken met groepen uit Leuven en uit Amsterdam, heeft aan dit proces een belangrijke bijdrage geleverd. Zo heeft Arnold Kester als eerste in de wereld een techniek ontwikkeld voor het statistisch poolen van $R O C$ curven en ook over het verzamelen en de kwaliteitsbeoordeling van diagnostisch onderzoek zijn ervaringen en richtlijnen gepubliceerd. Wij beschikken hier, dank zij de gedurende vele jaren volgehouden arbeid en zorgvuldigheid van Berna Schouten, over een databank van gepubliceerde diagnostische meta-analysen, die nergens zijn gelijke heeft en er zijn door onze mensen een tiental diagnostische meta-analysen gepubliceerd over een heel verscheiden waaier van onderwerpen. De samenwerking van verschillende disciplines en verschillende universiteiten heeft hier een stevige basis gelegd voor een beweging die wellicht nog vele jaren vruchten zal dragen.

\section{Co-morbiditeit en multimorbiditeit}

Hiervoor heb ik er reeds op gewezen dat de huisarts in zijn werk voortdurend geconfronteerd wordt met mensen met meerdere aandoeningen tegelijkertijd. Dat noemen wij multimorbiditeit als wij kijken naar het geheel van alle tegelijkertijd aanwezige aandoeningen of co-morbiditeit als het gaat om de relatie van één welbepaalde ziekte met andere ziekten. Marjan Van den Akker heeft het fenomeen multimorbiditeit en de oorzaken ervan uitvoerig beschreven. Maar hoe kan onderzoek naar oorzaken van multimorbiditeit ondersteunend werken voor de huisarts? Wellicht is het goed om even terug te keren naar de reden waarom wij indertijd met deze onderzoekslijn gestart zijn. In de dagelijkse praktijkvoering valt het steeds weer op hoe sommige mensen precies de ene ziekte op de andere stapelen, terwijl anderen nooit of slechts incidenteel 
ziek zijn. Uiteraard heeft deze indruk te maken met het ziektegedrag van de mensen: sommigen zullen voor een verkoudheid een arts raadplegen terwijl anderen dit slechts doen als zij nauwelijks nog anders kunnem. Uiteraard zijn er ook aandoeningen die als het ware in een ketting elkaar veroorzaken. Mensen met diabetes hebben nu eenmaal een hogere kans op allerlei aandoeningen dan andere mensen, vooral als die diabetes niet optimaal geregeld is. De indruk blijft echter dat hiermee niet alles verklaard is en dat de verschillen in vatbaarheid voor allerhande ziekten blijven bestaan. Als dit klopt is het belangrijk om dat te weten en om te leren wat deze verhoogde vatbaarheid veroorzaakt, zodat wij er misschien iets aan kunnen doen.

Dergelijk onderzoek is moeilijk. Wij hebben geen ideaal meetinstrument om deze vatbaarheid voor ziekte in het algemeen te meten. Wij hebben het aantal aandoeningen waaraan iemand tegelijkertijd lijdt en het aantal nieuwe aandoeningen dat in een bepaalde periode bij iemand nieuw opduikt, gebruikt als de best beschikbare benadering van dit fenomeen. Banale eenmalige aandoeningen (bijvoorbeeld verkoudheden) werden daarbij uitgesloten. De analyse hiervan heeft geleid tot het proefschrift van Marjan Van den Akker en tot een aantal onderzoekingen die daarop gevolgd zijn. Er zijn veel oorzaken gevonden die het voorkomen van multimorbiditeit elk een beetje groter maken en vele daarvan blijken niet beïnvloedbaar. De leeftijd is daar het belangrijkste voorbeeld van. Toch zijn er enkele, op het eerste zicht minder verwachte en minder klassieke factoren die een rol spelen. De toewijzing van de locus of control, de diepere opvattingen van het individu over wie of wat zijn of haar leven bepaalt, is éen daarvan. Het sociaal netwerk van de mens, met in de eerste plats diens gezin, is een tweede.

Locus of control toewijzingen vormen een kenmerk dat beïnvloed wordt door hetgeen een mens meemaakt. Zo kan een ernstige ziekte hier bijvoorbeeld verandering in brengen. Het is echter nog onduidelijk in welke mate dit kan beinnvloed worden door interventies van buitenaf, bijvoorbeeld éen of andere vorm van therapie. Wij blijven overigens nog steeds geîntrigeerd door de rol van depressies in het ontstaan van allerhande, ook somatische aandoeningen. Een aantal jaren geleden reeds hebben wij kunnen aantonen dat depressie bij mensen boven de vijftig de kans op lret ontstaan van dementie in de daarop volgende jaren meer dan verdubbelt. Anderen hebben gevonden dat na een depressie de kans op kanker toeneemt en dat de overlevingskansen van mensen met een hartinfarct kleiner worden naarmate zij hoger scoren op een depressie- 
schaal. Op dit ogenblik vergelijkt een ploeg met onder meer jonge onderzoekers als Agnes Schuurmans en Kim Ensinck de kans op een reeks van chronische ziekten bij mensen die al dan niet een depressie doormaakten. De aandoeningen zijn zo gekozen dat zij elk als indicator kunnen dienen voor een bepaald type aandoeningen.

Een probleem bij dit soort onderzoek is de definitie van het begrip depressie. Er zijn resultaten beschikbaar van degelijk uitgevoerd onderzoek bij willekeurig uitgekozen mensen aan huis en bij patiënten die de huisarts raadplegen, waarbij vragenlijsten gebruikt werden die toelaten depressie op te sporen volgens de criteria van de DSM, een Amerikaans classificatiesysteem voor psychiatrische aandoeningen dat momenteel in de psychiatrie algemeen gebruikt wordt. Volgens dergelijke registraties zou ongeveer $40 \%$ van de bevolking een psychiatrische aandoening vertonen, één op vier een stemmingstoornis en bijna één op vijf een majeure depressie. Dergelijke aantallen komen niet overeen met de dagelijkse ervaring van huisartsen. Zij kloppen ook niet met de resultaten van systematische huisartsgeneeskundige registratiesystemen. Op basis daarvan zou depressie voorkomen bij ongeveer $\mathbb{I}$ à $2 \%$ van de bevolking, cijfers die al veel redelijker lijken. Blijkbaar meten de clinicus die met zijn mensen praat en de epidemioloog die leest wat mensen invulden op een schriftelijke vragenlijst twee totaal verschillende dingen, ook al krijgen die dan dezelfde naam. Er loopt op dit ogenblik een multidisciplinaire werkgroep met Maastrichtse en Leuvense mensen om te proberen een beter zicht te krijgen op deze problematiek.

De relatie tussen gezin en ziekte.

Het onderzoek naar oorzaken van multimorbiditeit en de vaststelling dat het sociaal netwerk daar een belangrijke rol bij speelt, was de onmiddellijke aanleiding tot het starten van de onderzoekslijn gezinsgeneeskunde. Vijftien jaar geleden was gezinsgeneeskundig onderzoek vrij populair. In de huisartsgeneeskunde van de lage landen was het de tijd van de ondertussen overleden Prof. Frans Huijgen; die later eredoctor zou worden aan deze universiteit, van de eerste trainingen in systeemdenken voor huisartsen en van de Belgisch-Nederlandse Werkgroep Gezinsgeneeskunde. Internationaal was het de periode van de oprichting van het tijdschrift Family, Systems, Medicine. Na die topperiode is het echter erg stil geworden. Er waren blijkbaar andere prioriteiten. Nu wij de laatste tijd via een omweg terug bij de relatie tussen gezin en gezondheid 
belanden, blykt dat wij niet de enigen zijn en dat ook anderen terug op hetzelfde terrein actief worden, waarbij iedereen overigens ook op hetzelfde centrale probleem stuit: hoe kunnen wij gezinskenmerken en gezinsinteracties op een betrouwbare en relevante wijze in kaart brengen? Een goed antwoord op deze wraag hebben wij nog niet gevonden, maar wij zijn er mee bezig en ook hier zal samenwerking tussen disciplines en tussen centra wellicht wan groot belang zijn.

Het is misschien goed op dit ogenblik vast te stellen dat huisartsgeneeskundig epidemiologisch onderzoek zoals wij nu bespreken, enkel mogelijk is op basis van ziekteregistraties die zeer nauwgezet bijgehouden worden door groepen artsen die zich daar speciaal op toeleggen. Nederland heeft een aantal dergelijke registraties. Het Maastrichtse RNH netwerk is één van de grootste en meest bekende, met gegevens van ongeveer 100.000 patiềnten. Ook in Vlaanderen hopen wij rond de jaarwisseling de eerste 'echte" resultaten te kunnen presenteren van het Intego-netwerk, dat overigens bewust zo opgebouwd is dat haar resultaten in grote mate vergelijkbaar zullen zijn met de RNH data. Dergelijke registraties vormen als het ware een epidemiologisch laboratorium, waar epidemiologisch onderzoek gebeurt of vertrekt.

Daarnaast is er de belangrijke rol die studenten aan deze universiteit spelen in het wetenschappelijk onderzoek. Keuze-onderwijs, wetenschapsstages, OTG programma's en onderzoek in het kader van de huisartsopleiding bieden studenten uitvoerig de kans om in contact te komen met de dagelijkse praktijk van het onderzoek. Het enthousiasme en de inzet waarmee zij daar vaak op inspelen leidde vaak tot waardevolle prestaties, die hun neerslag vonden in internationale publicaties. Hun werk verdient ieders waardering.

I $k$ heb geprobeerd $U$ een beeld te schetsen van hoe de klinischepidemioloog via zijn onderzoek probeert ondersteunend te werken voor de huisarts in diens dagelijkse klinische arbeid. Ik heb ook proberen aan te geven welke moeilijkheden daarbij opduiken en hoe voor deze moeilijkheden steeds opnieuw oplossingen gezocht worden. De wisselwerking tussen clinicus en onderzoeker is daarbij essentieel. I k kan het dan ook niet laten om deze les af te sluiten met een oproep tot allen onder $\mathrm{U}$ die klinisch werkzaam zijn on voortdurend en kritisch oog te hebben voor tekortkomingen in onze kenuis, on vragen te formuleren en om te proberen daar antwoorden op te vinden. Overal in Belgie en 
Nederland zijn momenteel universitaire afdelingen beschikbaar die bereid en in staat zijn om daarbij ondersteuning te bieden. Het is tenslotte uit de woortdurende wisselwerking tussen praktijkvoering en wetenschappelijk onderzoek dat een belangrijk deel moet komen van de kennis die cen basis vormt voor de verbetering van de zorg voor mensen met allerhande vormen van pijn en miserie.

\section{Literatuur:}

1. Aertgeerts B. Screening for alcohol abuse or dependence $(\mathrm{PhD}$ thesis KULeuven). Leuven 2000.

2. Buntinx F (Ed). Huisarts en gezinsproblemen. Leuven; ACCO: 1987.

3. Buntinx F, Brouwers M. Relation between sampling device and detection of abnormality in cervical smears. A meta-analysis of randonised and quasi-randomised studies. Br Med J 1996; 313: 1285-1290.

4. Buntinx F, Essed GGM, Knottnerus JA, Crebolder HFJM. The effect of different sampling devices on the presence of endocervical cells in cervical smears. A systematic literature review. Eur J Cancer Prev 1994; 3: $23-30$.

5. Buntinx F, Kester A, Bergers J, Knottnerus JA. Is depression in elderly people followed by dementia? A retrospective cohort study based in general practice. Age Ageing 1996; 25: 231-233.

6. Buntinx F, Knottnerus JA, Crebolder HFJM, Essed GGM, Schouten $H$, Seegers $T$. Does feedback improve the quality of cervical smears? $A$ randomised controlled trial. Br J Gen Pract 1993; 43: 194-198.

7. Buntinx F, Truyen J, Embrechts P, Moreel G, Peeters R. Chest pain: an evaluation of the initial diagnosis made by 25 Flemish general practitioners. Fam Pract 1991; 8: 121-124.

8. Buntinx F, Truyen J, Embrechts P, Moreel G, Peeters R. Evaluating patients with chest pain using CART. Fam Pract 1992; 9: 149-153.

9. Buntinx $F$, Wouters $H$. The diagnostic value of macroscopic haematuria in diagnosing urological cancers. A meta-analysis. Fam Pract $1997 ; 14: 63-68$.

10. Buntinx F. The Cochrane Collaboration, information overload and European General Practice (Editorial). Eur J Gen Pract 1995; 1: 11-12.

11. Campens D, Buntinx F. Selecting the best renal function tests: a meta-analysis of diagnostic studies. Int J Techn Ass Health Care 1997; 13: $343-356$. 
12. De Lepeleire J, Buntinx $\mathrm{F}$. The link between depression and dementia in the elderly. Clin Geriatr 1997; 5: 82-90.

13. De Lepeleire J. De diagnose van dementie: het aandeel van de huisarts (PhD thesis KULeuven). Leuven 2000.

14. Devillé WLIM, Bezemer PD, Bouter LM. Publications on diagnostic test evaluation in family medicine journals: an optimal search strategy. J Clin Epidemiol: accepted.

15. Deville WLJM, van der Windt DAWM, Dzaferagic A, Bezemer PD, Bouter LM. The test of Lasèzue: systematic review of the accuracy in diagnosing herniated discs. Spine: accepted.

16. Dinant GJ, Knottnerus JA, Wersch JWJW. Discriminating ability of the erythrocyte sedimentation rate: a prospective study in general practice. Br J Gen Pract 1991;41:365-370.

17. Fijten $\mathrm{GH}$, Bligham $\mathrm{GH}$, Knottnerus JA. Occurence and clinical signifance of overt blood loss per rectum in the general population and in medical practice. B J Gen Pract 1994; 44: 320-25.

18. Gerritsma JGM, Smal JA. De werkwijze van huisarts en internist. Utrecht; Bunge: 1982.

19. Grol R (ed.). Huisarts en somatische fixatie. Nijmegen; NUHI: 1981.

20. Heyrman J. Huisartsgeneeskunde: een vak apart. Leuven; ACCO: 1994.

21. Hobus PPM, Hofstra ML, Boshuizen HPA, et al. De context van de klachten als diagnosticum. Huisarts Wet 1998; $31: 261-263$.

22. Hoogendam A, Buntinx $\mathbb{F}$, de Vet HCW. The diagnostic value of digital rectal examination in primary care screening for prostate cancer: a metaanalysis. Fam Pract 1999; 16:621-626.

23. Kester A, Buntinx F. Meta-analysis of ROC curves. Med Decis Making: accepted.

24. Knottnerus $J A$, Knipschild $\mathrm{PG}$, Sturmans $\mathrm{F}$. Symptoms and selection bias: the influence of selection towards specialists care on the relationship between symptoms and diagnoses. Theoretical Med 1989; 10:67-81.

25. Knottnerus JA. Interpretation of diagnostic data: an unexplored field in general practice. JRCGP 1985;35:270-74.

26. Knottnerus $\sqrt{ }$ A. Medical decision making by general practitioners and specialists. Fam Pract 1991;8:305-7.

27. Knottnerus JA. Prediction rules: Statistical reproducibility and clinical similarity. Med Decis Mak 1992;12(4):286-7.

28. Knottnerus JA; Dinant GJ. Medicine based evidence, a prerequisite for evidence based medicine [editorial] BMJ. 1997 Nov 1; 315(7116): 110910 
29. Knottnerus-JA. Application of logistic regression to the analys is of diagnostic data: exact modeling of a probability tree of multiple binary variables. Med-Decis-Making. 1992 Apr-Jum; 12(2): 93-108 30. Knottnerus-JA; Leffers-P. The influence of referral patterns on the characteristics of diagnostic tests. J-Clin-Epidemiol. 1992 Oot; 45(10): $1143-54$

31. Liedekerken BMJ, Hoogendam A, Buntinx F, Van der Weyden T, De Vet HCW. Prolonged cough and lung cancer: the need for more general practice research to inform clinical decision-making. $\mathrm{Br} J$ Gen Pract 1997; $47: 505$.

32. Muris JWM, Starmans R, Fijten GH, Crebolder HFJM, Krebbers $T$, Knottnerus JA. Abdominal pain in general practice. Fam Pract $1993 ; 10: 387-400$.

33. Muris JWM, Starmans R, Pop P, Crebolder HFJM, Knottnerus JA. Discriminant value of symptoms in patients with dyspepsia. J Fam Pract 1994;38(2):139-43.

34. Oosterhuis WP, Niesen RWLM, Bossuyt PMM. The science of systematic reviewing studies of diagnostic tests. Clin Chem Lab Med 2000; 38: $577-588$.

35. Sackett DL, Haynes RB, Tugwell P. Clinical epidemiology: a basic science for clinical medicine. Boston, Little, Brown and co: 1985.

36. Sackett DL, Rosenberg WMC, Gray JAM, Haynes RB, Richardson WS. Evidence based medicine: what it is and what it isn't. BMJ 1996; 312: $71-72$.

37. Spitzer RL, Williams JBW, Kroenke K, et al. Utility of a new procedure for diagnosing mental disorders in primary care: the Prime-MD 1000 study. JAMA 1994; $272:$ : 1749-1756.

38. Starmans R, Muris JWM, Fijten GH, Schouten HJA, Pop P, Knottnerus JA. The diagnostic value of scoring models for organic and non-organic gastrointestinal irritable-bowel syndrome. Med Dec Making $1994 ; 14: 208-216$.

39. Stoffers HEJH, Kester ADM, Kaiser V, et al. Diagnostic value of signs and symptoms associated with peripheral arterial occlusive disease seen in general practice. A multivariable approach. Med Decis Making $1997 ; 17: 61-70$.

40. Stoffers HEJH, Kester ADM, Kaiser V, Rinkens PLEM, Kitselaar PEHM, Knottnerus IA. The diagnostic value of the measurement of the ankle-brachial systolic pressure index in primary health care. J Chin Epidemiol 1996:49:140》-1405. 
41. Van den Acker M, Buntinx F, Metsemakers JFM, Knottnerus JA. Marginal impact of psycho-social factors on multimorbidity; results of an explorative nested case-control study. Soc science Med 2000; 50: 16791693.

42. Van den Acker $M$, Buntinx F, Metsemakers JFM, van der Aa M, Kunottnerus JA. Psycho-social determinants of multimorbidity: a prospective study. J Psychosom Res: accepted.

43. van den Akker $M$, Buntinx $F$, Knottnerus JA. Comorbidity or multimorbidity: what's in a name? A review of literature. Eur J Gen Pract 1996; 2: 65-70.

44. van den Akker M, Buntinx F, Metsemakers JFM, Roos S, Knottnerus JA. Multimorbidity in general practice; prevalence, incidence, and determinants of co-occurring chronic and recurrent diseases. J Clin Epidemiol 1998; 51: 367-375.

45. Van den Akker M. Multimorbidity in a general practice population: prevalence, incidence and determinants of multiple pathology $(\mathrm{PhD}$ thesis UM). Maastricht: 1999.

46. Van den Ende J, Derese A, Lemiengre M. De kracht van een argument: de waarde van diagnostische gegevens. Huisarts $\mathrm{Nu} 1996 ; 25: 298-305$.

47. Van den Ende J, Derese A, Vervaeck N. Complexe analyse: de kroon op het diagnostisch werk. Huisarts Nu 1996; 25: 329-337.

48. van der Weijden $T$, Ijzermans CJ, Dinant GJ, van Duijn NP, Dyserinck $\mathrm{HC}$, Buntinx $\mathrm{F}$. Identifying relevant diagnostic studies in Medline. Fam Pract 1997; 14: 204-208.

49. Vandenbroucke JP. Medical journals and the shaping of medical knowledge. Lancet 1998; 352: 2001-2006.

50. Wouters $\mathrm{H}$, Van Casteren V, Buntinx F. Rectal bleeding and colorectal cancer in general practice: diagnostic study. BMJ 200; 321: 998-999. 